\title{
THE FIRST PLANT COLLECTORS IN KASHMIR AND THE PUNJAB
}

\author{
Ralph R. Stewart ${ }^{1}$
}

\section{Introduction}

I must be Rogers McVaugh's oldest pupil. I did not know him until I was 70 and about to retire from Gordon College, Rawalpindi, Pakistan, where I had worked from 1911 until 1960, except for occasional furloughs in this country. When Rogers took charge of the angiosperm herbarium in 1960, following the death of 'Uncle' Harley Bartlett, his distinguished predecessor, he found that he had a legacy of some 150,000 specimens in bales and bundles in various store rooms. Some of these specimens had been in storage for fifty years. As about 30,000 of these specimens were from India, McVaugh looked around to find someone with a knowledge of Indian plants. A friend told him that I was retiring from Gordon College and he wrote to inquire if I were available. As I did not want to move into an Old Folks Home we gladly moved to Ann Arbor.

Rogers may not have realized that I was his pupil but living and working in his herbarium, and watching the way he did things was an inspiration to me. I had been a lecturer and administrator in a missionary college and a plant collector in my free time and was glad to learn how things were done in a good herbarium.

Eighteen years have passed and I am still working in a far corner of his herbarium and he is about to follow me into official retirement. If I am not much mistaken the years ahead will be even more fruitful, botanically, than those which are behind him. Free from committee meetings and official duties he will be able to use all of his talents to advance Mexican botany and continue his work on plant nomenclature. I have seen him daily for all of these years and wonder if he has ever arrived at work after $8 \mathrm{~A}$.M. He never seems to be sick and if he goes home at five he is likely to be back at work again after supper. I do not come to the herbarium on Saturdays and Sundays, but he does, and he seems to thrive on such a timetable for his health seems to be excellent.

I do not suppose that there is a more faithful curator in the country. I have never seen an insect in any of our cases. He usually has a crew of five or six mounters at work and I have never seen better mounted specimens anywhere. The atmosphere of the mounting room is cheerful and relaxed. His $\mathrm{Ph}$. D. students have not had an absentee landlord. They are never neglected and I wish that I had had as good a training as they have received when I was studying for my doctorate more than 60 years ago.

After coming to Ann Arbor I worked for two years getting the Indian specimens into the herbarium and when the National Science Foundation grant supporting me ran out I was advised to try for one of my own to work on the flora of Pakistan, and Kashmir. India had been divided in 1947 and the place where I lived had become part of Pakistan.

Rawalpindi was a good center for a botanist. It is only ten miles from the Himalayan foothills. The Murree and Hazara hills which rise to $9000^{\prime}$ are within 40 miles. Students could be taken into the mountains by bus in a couple of hours and there were good places to collect within ten or twelve miles. The valley of Kashmir was only 200 miles away. The road was closed in 1947 but between 1911 and 1947 I

1 Herbarium, University of Michigan, Ann Arbor, Michigan 48109, U.S.A. 
had spent many vacations in Kashmir and had built up a good collection of Kashmir plants.

I worked for ten years on "An Annotated Catalogue of the Plants of Pakistan and Kashmir" which was published in Karachi at the expense of the U.S. Dept. of Agriculture in 1972. In preparing an appendix, giving a few facts about 394 collectors, I began to get interested in the collectors, especially those who had been the pioneers. I began to wonder what it was like to collect plants in the Punjab and Kashmir 150 years ago when the Sikhs were still ruling in the whole area before the British took over in 1849 . What was it like when there were no good roads; when a good day's march was from 12 to 15 miles; when there were no telephones, telegraphs, hospitals or modern medicine? What was it like when there were no cures for plague, smallpox, cholera or malaria? Travel was so unsafe that important people travelled with armed escorts and ordinary travellers had to wait for a caravan they could join in order to enjoy the security of numbers. In spite of all these difficulties and more, the pioneers and explorers came from a number of countries. It took months by sailing ship to reach India by the Cape of Good Hope route and the land route through Turkey and Persia and the Persian Gulf also took months. When the traveller wanting to go to Kashmir reached Bombay, he still had weeks and weeks of travel before him. It was not until 1860 that the railroad reached Rawalpindi. In 1912 I was able to ride a push bike to Kashmir in five days. Moorcroft, Falconer, and Jacquemont went on horseback but they could not go faster than their coolies and pack animals. They did not find rest houses at the end of each day's march but had to take their own tents.

The only book which I found of much use in my search for data about those who had collected in India and Kashmir was I.H. Burkill's "Chapters on the history of botany in India" (Botanical Survey of India, Calcutta, 1965). The book is a mine of information but you have to dig hard for the ore, as the book is arranged in such a manner that the references to each person are scattered through the book, which does not deal with those who began work after 1900 .

To obtain additional material which was not in Burkill I spent a good deal of time in the Travels Room at Kew reading the books of the pioneers I was interested in. Almost all of them were authors and if they did not reach home, others used their notes or diaries.

As my contribution to the Festschrift of Dr. Mc Vaugh I would like to introduce to a modern audience some of the pioneers who reached the Punjab and Kashmir many years ago.

\section{William Moorcroft (1765-1825)}

The very first person to do any collecting in Western Tibet and Kashmir was a veterinary surgeon. He was the first Englishman to have a degree in veterinary surgery and he was the first veterinarian to be employed by the East India Company. When he reached India all of Central Asia and most of the Himalayas were blanks on the map. The British needed to know where the great Himalayan rivers came from, and what lay on the other side of the Himalayas. In 1812, without permission from the authorities, taking a man named Hearsay with him, he crossed the Himalayas into Tibet and reached the sources of the Sutlej in the Manasarovar Lakes and tried to bring back a flock of the goats which supplied the famous wool used to make shawls. He collected a bundle of plants, the first to have come from far back in the mountains.

In 1819, with two companions, Guthrie and Trebeck, again without permission, he started out to go clear to Turkestan to buy stallions to bring back to India to improve the Indian breeds. To avoid the Sikhs he did not try to enter Kashmir by the front door but started toward Leh in Western Tibet, the starting point for the long and dangerous road to Turkestan over $18,000^{\prime}$ passes, and mostly through uninhabited 
wastes. No one knows what his real motives were. Was he really after horses or did he want to find out what lay beyond the Himalayas? He aimed to reach Leh by a little used road from Kulu to Lahul in the Punjab Himalaya and then over the Baralacha Pass into Rupshu and over the high plateaus to Leh. Reaching Leh he tried without success to get permission to proceed to Turkestan. Apparently undismayed he waited and used the time to explore Ladak and Kashmir, asking innumerable questions. In 1822 he made a visit to the Vale of Kashmir, after securing permission with much difficulty. In Kashmir he was followed wherever he went.

Apparently discouraged after a three year delay he started to go to the Punjab by the Jhelum Valley route. When the party arrived near Uri a petty Muslim chieftain demanded Rs.15,000 to let him pass. A rupee would buy a good deal in those days, more than ten times what it will buy today. Moorcroft offered Rs. 500 to be allowed to pass. His offer was refused and the party returned to Srinagar and went to the Punjab by another route. He crossed Afghanistan and reached Bokhara where he died. It is not certain whether he died from disease or whether he was murdered.

Before leaving Kashmir Moorcroft prepared a bundle of 23 specimens he had gathered and sent it to Wallich at Calcutta. Many of his specimens were new, including such well known species as Gentiana moorcroftiana and Salvia moorcroftiana and so he is credited with being the first to collect in Ladak (Western Tibet) and Kashmir.

\section{Victor Jacquemont (1800-1832)}

The first, or possibly the second, to collect in the Punjab and the first real botanist to collect in Kashmir was a young and very capable Frenchman who was sent by the National Museum of France to India to collect plants. He was a man of good family, named Victor Jacquemont. He first collected in the region of Pondicherry, a French possession, and then he worked north. He must have been an attractive person for he was welcomed by the British officials, high and low. At that period there were a number of European soldiers of fortune in high positions under Ranjit Singh, the Sikh Maharaja, who ruled the Punjab and Kashmir. One of these was General Allard [for whom the genus Allardia, now Waldheimia was named]. Word reached Allard that a fellow countryman was collecting plants in India and he wrote to him, suggesting that he come north and visit the Punjab. The Maharaja agreed to the invitation as he had had reports from his agents in India that Jacquemont was an unusually wise and capable person. At that time the British frontier was at the Sutlej and the Maharaja had his visitor met at the border as though he were an ambassador. He was brought to Lahore where he was wined, dined, and provided with dancing girls. This was in 1830 , when he was allowed to make a collecting trip in the Salt Range, an interesting region just north of the Jhelum River. In this range there are extensive salt mines which have been mined for centuries.

He was then given permission to collect in the Valley of Kashmir and surrounding mountains in 1831. All the time he was in the Punjab and Kashmir his expenses were met by Ranjit Singh. Jacquemont, accompanied by a sizeable escort, went to Kashmir by the Pir Panjal route, and although he was the guest of the ruler he met with many difficulties, the worst being an effort by an unhappy Hill raja to hold him as a hostage because the Maharaja owed him something. After making a large collection during the summer he left Kashmir by the eastern, i.e. the Banihal route. He moved as far south as Poona in the Bombay Presidency, and then went to Bombay where he is said to have died of malaria, though Burkill says "from his hard life". His collections reached Paris safely and were studied by Cambessèdes and Decaine. The names of the plants he collected, and his routes, are detailed by Cambessèdes \& Decaine in "Plantae rariores, quas in India orientali collegit Victor Jacquemont", Voyage dans l'Inde pendant les années 1828-32 (Pars Bot., pp. 1-56, 1841-5, Vol. IV. Paris). 
The directors of the East India Company did not recruit people in Britain to fill the few botanical posts they maintained but picked out men they had already recruited for other posts, doctors, soldiers or civil servants who had demonstrated an interest and ability in botany. Royle went to India as a doctor with a great interest in Materia Medica. He was first assigned to Meerut in the United Provinces as a doctor but when Govan the Civil Surgeon and Sup't of the Botanical Garden at Saharanpur retired, Royle was given the post although he had had little experience. The Company had an important garden near Calcutta and one at Saharanpur which was maintained to grow plants that did not do well in the tropical Bengal climate. The collectors based there were to collect in the mountains northwest of Nepal. It was not much of a garden [covering only 40 acres] but Royle rapidly developed it and in 1828-9 and 1831 he sent collectors into Kashmir with the guidance of shawl dealers who were returning to Kashmir after selling their wares.

It is said that, when Jacquemont visited Saharanpur in 1830 on his way to Lahore, Royle was able to show him 100 living Kashmir plants which had been brought in by his collectors. Royle's medical duties were such that he could not go to Kashmir in person, but he was able to help Jacquemont and his book which he worked on at Kew on his first furlough, "Illustrations of the botany and other branches of the natural history of the Himalayan Mts. and Cashmire" (2 vols., London, 1833-1840), was published before the posthumous volumes of Jacquemont. Royle's book is illustrated with coloured plates and is an excellent piece of work.

When Royle retired he took his personal herbarium to Liverpool and gave his collection of 12,000 specimens to an obscure pharmaceutical museum in Liverpool, England, where it was lost sight of for 100 years. When it was discovered it was badly damaged. This can be cited as a good example of what not to do with a valuable collection.

Godfrey Thomas Vigne (1801-1863) and Karl Alexander Anselm von Huegel (17951870)

Soon after Maharaja Ranjit Singh had permitted Jacquemont to visit Kashmir he allowed two more pioneer wanderers to visit Kashmir in 1835. Vigne was an Englishman and von Huegel a German nobleman by birth, but an Austrian by adoption. Neither did much botanizing in Kashmir. The bundle of plants which Vigne accumulated in three years contained only about 90 specimens and they were not first class. They were given to Royle, who named them. Vigne added this list and some botanical notes Royle gave him as a supplement to his book "Travels in Kashmir, Ladak and Iskardo" (1,2, London, 1842). Although Vigne carried a plant press, Burkill states that he only did some collecting near Dras on the Ladak Road and in the Astor Valley near Nanga Parbat.

Von Huegel knew a good deal about botany and made a collection in the Nilgiri Hills of South India but in his big four volume work entitled "Kaschmir und das Reich der Seik (Sikh)" (Stuttgart, 1844), there is no botany. His collection of plants is in Vienna, Austria, and in 1845 Grisebach published Gentiana huegelii from Kashmir which shows that he did collect and that his Kashmir specimens reached Vienna.

Vigne and von Huegel met in Kashmir and did some traveling in the valley together and then both returned to the Punjab by the Hazara route. Von Huegel did not return to Kashmir but went on to Australia and Tasmania, but Vigne returned to Kashmir in 1836 and remained exploring for two years conducting rough surveys and paying special attention to the routes and the passes through the mountains. He must have thought that this kind of information might be required by the East India Company some day. 
The second to collect in Baltistan was a very different sort of person from Vigne. He was no dilettante, but a thorough scientist. Although he was trained as a zoologist and paleontologist he held important botanical positions, first as successor to Royle in charge of the Saharanpur Garden, and then he succeeded Wallich at Calcutta. While in charge at Saharanpur, Sir Alexander Burns was sent to Afghanistan on a Trade Mission, and Falconer was ordered to accompany him as botanist. When the Mission arrived near the Afghan frontier they found that their Mission was not acceptable to the Afghans. On this trip Falconer had collected on his way and he is probably the first to have collected north of the Salt Range. When the Afghan trip was abandoned Falconer was directed to penetrate into the mountains to see what useful plants he could find. The botanical interest of the company was not in plants in general. Falconer tried to ascend the Indus but after three days the people at Darband would not let him proceed further so he entered Kashmir via Hazara. He wintered in Kashmir and in 1837 followed the Gilgit route, i.e. over the Rajdani Pass to the Kishenganga Valley and followed Vigne to the Indus. He met Vigne in Baltistan and as Vigne almost certainly did not do any collecting in Baltistan, Falconer deserves credit for being the first collector. He ascended the Shigar River as far as Askole. On going home on leave in 1841 he took 76 packages of plants and five tons of mammalian and other fossil bones collected in the Siwaliks.

Falconer's chief claim to fame is his work on the remarkable mammalian fauna of the Siwaliks. He did not name his plant collections but they were left in India House in London where no one paid any attention to them. When Sir Joseph Hooker was starting to prepare his Flora of British India he rescued Falconer's specimens but some of them were damaged.

\section{John Martin Honigberger (1795-?)}

Burkill credits Honigberger with being the first to do any collecting in Afghanistan and Jacquemont for being the first in the Punjab. Burkill does not seem to have read Honigberger's book or to know that he had lived for fifteen years in Lahore, part of the time as physician to the court. Honigberger's book, "Thirty-five years in the East. Discoveries and sketches relating to the Punjab and Cashmire in connection with medicine, botany etc." ( 2 vols., London), seems to be very rare but I found a copy at Kew which the doctor had given to Thomas Thomson. In the second volume he lists 476 species which he evidently knew well. He knew both the Latin and vernacular names. There are 31 plates and usually four illustrations per plate.

Honigberger's book is so arranged that it is in places hard to figure out dates and there is no indication when his species were collected. None may have been collected before 1830 when Jacquemont visited the Salt Range. There is no doubt, however, that Honigberger did far more collecting in the Punjab than Jacquemont did and that he knew far more about what he was collecting. On page 53 he mentions meeting Jacquemont. Many of his plants were collected in Kashmir, probably in 1849 after the British had defeated the Sikhs, for he states that he went there with the permission of Maharaja Gulab Singh and the British. The rest were from the Punjab.

It is a mystery to me why Honigberger went home by the way he did. I would have expected him to descend the Indus to the Arabian Sea, go by boat through the Persian Gulf and then cross Persia to Turkey. The road from the Indus across the Sulaiman Range into Afghanistan and on to Kabul and north to the Oxus was about as dangerous as any in that part of a dangerous world. The Waziris stole camels from his caravan. It was in the hot weather and he found little to collect because of locusts and the extreme heat. He lost a horse from the heat and he was robbed at Bamian north of Kabul. He was probably using the same route which Moorcroft had taken on his way to his death a few years before. One had to be tough to survive in those days. 
Honigberger remained in Europe until 1836 and he states that on returning to Lahore he was made Physician to the Court. When the Maharaja died he was present when the monarch's eleven wives were burned alive on his funeral pyre.

Honigberger's specimens are in Vienna and someone told me that many of them were lying there unnamed. After 140 years Dr. K. H. Rechinger is using them as he prepares his Flora Iranica.

\section{Thomas Thomson (1817-78)}

Like so many of the early British botanists in India Thomson was a doctor. He had studied botany under Sir William Jackson Hooker, who became the first Director at Kew, and he was the friend and classmate of Joseph Dalton Hooker, the son of Sir William who succeeded his father. During his first few years in India he was assigned to medical posts but he collected plants wherever he was working. In 1847 the opportunity came for him to explore unknown territory on the frontiers of Kashmir and into Tibet. The British had not yet taken over the Punjab and Kashmir, but they were anxious to know the course of the Indus and to fill in the numerous blank spaces on the map. A Kashmir Frontier Commission with Major Alex. Cunningham as its head, Thos. Thomson as doctor and botanist, and Capt. Henry Strachey as surveyor was appointed. It has been called a Tibetan Boundary Commission but if the Tibetans were notified they did not turn up or meet this Commission. Strachey surveyed the Upper Indus and did a little collecting. Cunningham and Thomson went to Leh, the capital of Ladak where they separated and Thomson began two years of travel, mostly in unknown territory.

Thomson went from Leh westward to Nubra and then descended the Shyok Valley through Baltistan to Skardo. He intended to return to Kashmir before winter closed the Zoji La but he did not start in time and had to winter in Skardo. The next year he traveled extensively, crossing the whole of Kashmir to the Chamba line and covered much the same ground that Vigne had covered about ten years before without collecting any plants. He explored Budrawah and Kishtwar and entered Western Tibet (Ladak) through Zanskar. He crossed the 15,000 ft. high plateaus of Rupshu, the home of the wild yak and wild ass. He crossed the Indus and went to the $18,000 \mathrm{ft}$. Karakorum Pass on the road to Turkestan. Based on two years of work Thomson published in 1852 "Western Himalaya and Tibet" (501 pp., London). It is a diary of his work, useful but too prosaic. He must have escaped dangers and had experiences which would have added materially to the interest of the bare bones of his trip.

Thomson was a good collector in some ways. He was thorough and made many good specimens but his labels leave much to be desired. Most of them simply are marked Tib. Occ. (W. Tibet). As many of his specimens are type collections we would like to know more exactly where he found them. After he retired from India he went to Kew and helped his friend Sir Joseph prepare the first volume of the Flora of British India. Dying in 1878 he had only helped with one volume.

\section{The Schlagintweit Brothers}

The Schlagintweit brothers did not work while the Sikhs were in power but they did so much exploring in British India and beyond its borders, where no one else had been, that they should be remembered along with the previous pioneers. The ground the brothers covered in four years, much of it in unknown, uninhabited mountainous country, is surprising.

There were three brothers, Hermann (1836-1882), Adolf (1829-1857), and Robert (1833-1885) who came to India in 1854 as physical geographers under the patronage of the King of Prussia. The East India Company appreciated their work and employed them as explorers. The brothers employed plant collectors and their collections went to Kew and were distributed from there. The second brother got as far as Kashgar 
where he was murdered. The brothers, probably to cover more ground, did not always work together. They explored the Tibetan plateau to Gartok, in the Karakorum, the headwaters of the Punjab rivers and in many parts of India. In 1861 Hermann published the "Results of a scientific mission to India and High Asia" (4 vols, and Atlas, Leipzig).

The brothers worked in India for four years. After the Mutiny of 1857 the East India Company was dissolved and the Schlagintweits were not employed by the new government of India. As Hermann's volumes were published in Germany and in German, few copies could have reached India. I do not remember having seen them anywhere. 